\title{
Effects of Self-Assembling Peptide P11-4, Fluorides, and Caries Infiltration on Artificial Enamel Caries Lesions in vitro
}

\author{
Richard J. Wierichs Julian Kogel Julian Lausch Marcella Esteves-Oliveira \\ Hendrik Meyer-Lueckel
}

Department of Operative Dentistry, Periodontology and Preventive Dentistry, RWTH Aachen University, Aachen, Germany

\section{Keywords}

Esthetics · Caries infiltration · Demineralization · Enamel · Fluoride $\cdot$ In vitro $\cdot$ Regeneration · Self-assembling peptide $\cdot$ White spot lesions

\begin{abstract}
The application of a self-assembling peptide on noncavitated caries lesions is supposed to be a feasible approach to facilitate remineralization and mask their unfavorable appearance. However, demineralizing conditions are common in the oral environment, so the aim of this $\mathrm{pH}$-cycling study was to compare recommended and novel treatment methods regarding their ability to hamper demineralization and as a consequence mask artificial enamel caries lesions. Artificial caries lesions were prepared in bovine enamel and randomly allocated to 11 groups $(n=22)$. Treatments before $\mathrm{pH}$-cycling were as follows: the application of a self-assembling peptide (Curodont ${ }^{\mathrm{TM}}$ Repair $[\mathrm{C}]$ ), a low-viscosity resin (Icon $\left.{ }^{\circledR}[\mathrm{I}]\right), 2$ fluoride solutions (10,000 ppm F F $^{-}$Elmex fluid [E] and 43,350 ppm F-: Tiefenfluorid $\left.{ }^{\circledR}[\mathrm{T}]\right)$, and no intervention (N). During pH-cycling (28 days, $6 \times 60$ min demineralization/ day) half of the specimens in each group were brushed (10 s; $2 \times /$ day) with either fluoride-free (named e.g., $C_{0}$ ) or $\mathrm{NaF}\left(1,100\right.$ ppm F-; e.g., $\left.\mathrm{C}_{1}\right)$ dentifrice slurry. In another sub-
\end{abstract}

\section{KARGER}

(C) 2017 S. Karger AG, Basel

E-Mail karger@karger.com

www.karger.com/cre group specimens were $\mathrm{pH}$-cycled but not brushed $\left(\mathrm{N}_{\mathrm{NB}}\right)$. Differences in integrated mineral loss $(\Delta \Delta Z)$, lesion depth $(\Delta \mathrm{LD})$, and colorimetric values $(\Delta \Delta \mathrm{E})$ were calculated between values after pre-demineralization, surface treatment, and $\mathrm{pH}$-cycling. Specimens of $\mathrm{C}_{0}, \mathrm{C}_{1}, \mathrm{~N}_{\mathrm{NB}}, \mathrm{N}_{0}, \mathrm{~N}_{1}, \mathrm{~T}_{0}$, and $\mathrm{E}_{0}$ showed significantly increased $\Delta Z$ and $L D$ values after $\mathrm{pH}$-cycling ( $p \leq 0.003$; paired $t$ test). $\mathrm{C}_{0}, \mathrm{C}_{1}, \mathrm{~N}_{\mathrm{NB}}$, and $\mathrm{N}_{0}$ showed significantly higher changes in $\Delta \Delta \mathrm{Z}$ than $\mathrm{E}_{1}, \mathrm{I}_{0}, \mathrm{I}_{1}$, and $\mathrm{T}_{1}(p<0.001$; ANOVA). Significantly reduced colorimetric values could only be observed for $I_{1}, I_{0}, E_{1}$, and $E_{0}$ after treatment and after $\mathrm{pH}$-cycling ( $p \leq 0.027$; paired $t$ test). In conclusion, under the conditions chosen only the application of a low-viscosity resin could mask caries lesions significantly, whereas self-assembling peptides could neither inhibit lesion progression nor mask the lesions considerably.

(c) 2017 S. Karger AG, Basel

Although efforts in caries prevention have resulted in a trend towards fewer caries lesions [Michaelis and Schiffner, 2006], initial caries lesions can still frequently be observed. These rather shallow lesions, being detectable within 2 weeks after lesion initiation in vivo [Holmen et al., 1985], have an opaque appearance as light is scattered differently within sound enamel (92\% hydroxyapatite

Dr. Richard J. Wierichs

Department of Operative Dentistry, Periodontology and Preventive Dentistry RWTH Aachen University

Pauwelsstrasse 30, DE-52074 Aachen (Germany)

E-Mail rwierichs@ukaachen.de 
volume, $6 \%$ water volume, and $2 \%$ organic volume; hydroxyapatite refractive index $[\mathrm{RI}]=1.62$ ) and lesion areas are filled with air (decreased hydroxyapatite volume and higher pore volume, later partially replaced by air [RI = $1.00]$ and water [RI = 1.33]) [Kidd and Fejerskov, 2004]. Thus, initial lesions are often called white spots. Following orthodontic treatment with fixed appliances white spots showed a prevalence ranging between 50 and $97 \%$ [Gorelick et al., 1982; Boersma et al., 2005]. Therefore, several different treatment procedures to reverse, arrest, mask, or reduce the incidence of the lesions have been proposed. However, current noninvasive interventions do not seem to be sufficient to completely avoid the formation as well as the progression of (initial) caries lesions [Meyer-Lueckel and Paris, 2013].

White spots might be reversed with fluorides or casein-phosphopeptide amorphous calcium phosphates (CPP-ACP), both enhancing remineralization [Willmot, 2004; Altenburger et al., 2010]. Microabrasion with an $\mathrm{HCl}$ pumice [Waggoner et al., 1989; Akin and Basciftci, 2012] or infiltration using a low-viscosity resin [Paris et al., 2013] have also been suggested. Nonetheless, the clinically visible success varies widely. Fluoride and CPPACP did not reveal a distinct positive clinically visible effect [Bailey et al., 2009; Rocha Gomes Torres et al., 2011]. Microabrasion, even though it reduced the unfavorable appearance of white spot lesions, resulted in a substantial loss of enamel [Meireles et al., 2009]. Contrastingly, infiltration, being initially developed to arrest proximal caries lesions [Paris et al., 2007], was suitable for masking white spot lesions [Knosel et al., 2013; Paris et al., 2013].

A relatively new approach to possibly reverse and mask white spot lesions is the application of the self-assembling peptide P11-4 [Aggeli et al., 1997]. Once the P11-4-containing solution has been applied the peptide diffuses into the lesion. Within the lesion it is supposed to self-assemble spontaneously and to produce 3-dimensional gels comprised of so-called $\beta$-sheet aggregates. Thereby, the attachment of $\mathrm{Ca}^{2+}$ and $\mathrm{PO}_{4}{ }^{3-}$ from saliva is supposed to be enhanced [Kirkham et al., 2007]. In a previous noncontrolled clinical trial [Brunton et al., 2013] the clinical appearance of class $\mathrm{V}$ white spot lesions was improved after a single application of a P11-4-containing solution. Although these results were stable for 6 months, only 11 lesions were included and the study design included neither a positive (e.g., fluoridation) nor a negative control (placebo/no treatment). In vitro, a significant increase in the subsurface microhardness could be observed after the application of Curodont ${ }^{\mathrm{TM}}$ Repair [Schmidlin et al., 2016]. Furthermore, after the applica- tion of Curodont ${ }^{\mathrm{TM}}$ Repair significantly improved quantitative light-induced fluorescence values could be observed in another in vitro study, but only when 2 control groups were merged in the analysis [Jablonski-Momeni and Heinzel-Gutenbrunner, 2014]. Nonetheless, in both in vitro studies enamel specimens were solely stored in remineralizing solutions for 4 or 12 weeks, respectively. No demineralization solution was used intermittently to simulate oral $\mathrm{pH}$ fluctuations that still occur on surfaces in need for remineralization.

Thus, the purpose of the present $\mathrm{pH}$-cycling study was to compare recommended and novel treatment methods regarding their ability to hamper slight demineralization and, as a consequence, mask artificial enamel caries lesions under these conditions. The null hypothesis was that no significant differences in the change of mineral loss as well as colorimetric values would be observed after the application of fluorides, the peptide P11-4, or an infiltrant, and subsequent $\mathrm{pH}$-cycling - all compared with negative controls.

\section{Materials and Methods}

\section{Specimen Preparation}

Bovine incisors were obtained from freshly slaughtered cattle (negative BSE test) and stored in $0.08 \%$ thymol. Teeth were cleaned and 300 enamel blocks $(5 \times 3.5 \times 3 \mathrm{~mm})$ were prepared (Exakt 300 ; Exakt Apparatebau, Norderstedt, Germany) (Fig. 1). The enamel blocks were embedded in epoxy resin (Technovit 4071; Heraeus Kulzer, Hanau, Germany), ground flat, and polished (4,000 grit, silicon carbide; Phoenix Alpha, Wirtz-Buehler, Düsseldorf, Germany; Mikroschleifsystem Exakt; Exakt Apparatebau).

\section{Lesion Formation}

One-third of the surface of each specimen was covered with acid-resistant nail varnish (sound control area, window SC). In each of 300 specimens 1 artificial lesion was created ( $\mathrm{pH} 4.95 ; 21$ days) [Buskes et al., 1985]. After pre-demineralization half of the artificial lesion was covered with resin (Tetric EvoFlow, A4; Ivoclar Vivadent AG, Schaan, Principality of Liechtenstein) (demineralized baseline area, window DB). Each of the second halves of the artificial lesions (demineralized treatment area, window DT) remained uncovered for the treatment procedure. In this way, 242 specimens with a mean ( $95 \%$ confidence interval) baseline color difference between SC and DT ( $\left.\Delta \mathrm{E}_{\text {baseline }}\right)$ of $13.2(12.7 ; 13.6)$ were chosen from the 300 specimens originally prepared.

\section{Surface Treatments}

Specimens were randomly allocated to 11 experimental groups. Interventions before $\mathrm{pH}$-cycling were as follows: application of a product containing self-assembling peptides (Curodont ${ }^{\mathrm{TM}}$ Repair $\left[\mathrm{C}_{0}\right.$ and $\left.\mathrm{C}_{1}\right]$ ), a low-viscosity resin ( $\operatorname{Icon}^{\circledR}\left[\mathrm{I}_{0}\right.$ and $\left.\mathrm{I}_{1}\right]$ ), a fluoride solution containing $10,000 \mathrm{ppm} \mathrm{F}^{-}$(Elmex fluid $\left[\mathrm{E}_{0}\right.$ and $\left.\mathrm{E}_{1}\right]$ ), a fluoride solution containing $43,350 \mathrm{ppm} \mathrm{F}^{-}$(Tiefenfluorid ${ }^{\circledR}\left[\mathrm{T}_{0}\right.$ and $\left.\left.\mathrm{T}_{1}\right]\right)$, and no intervention $\left(\mathrm{N}_{0}, \mathrm{~N}_{1}\right.$, and $\left.\mathrm{N}_{\mathrm{NB}}\right)$. 


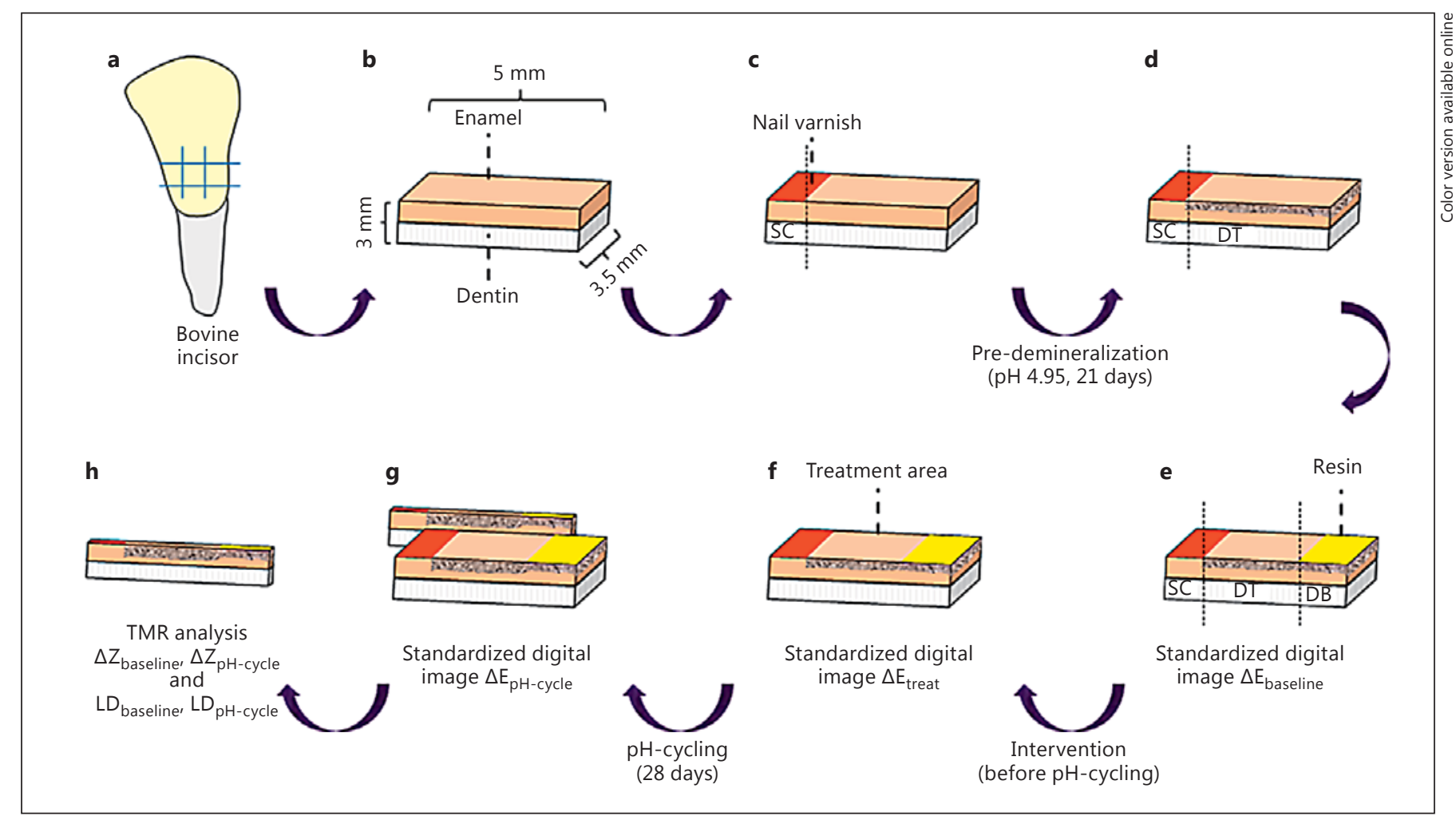

Fig. 1. Specimen preparation. a Frontal view of bovine incisor and lines for cutting perpendicular and parallel to the long axis of the tooth crown. b Prepared specimens $(5 \times 4 \times 3.5 \mathrm{~mm})$. c Specimen covered with acid-resistant nail varnish (sound control area [SC], red). d Pre-demineralized specimen (demineralized treatment area [DT]). e Specimen covered with resin (demineralized baseline area [DB], yellow). f Specimen after the application of the agents. g, $\mathbf{h}$ Preparation of the thin sections after $\mathrm{pH}$-cycling for transversal microradiographic analysis.

Curodont ${ }^{\mathrm{TM}}$ Repair (Credenits AG, Windisch, Switzerland) was applied according to the manufacturer's instructions with the exception of the etching time. The surface of the lesion was cleaned using a brush (Pro Cup No. 990/30; Hawe Neos Dental, Bioggio, Switzerland) and, using 3\% hypochlorite solution (Hedinger, Stuttgart, Germany) for $20 \mathrm{~s}$, rinsed using distilled water for $30 \mathrm{~s}$, etched using 37\% phosphoric acid gel (Total Etch; Ivoclar Vivadent) for $5 \mathrm{~s}$ [Gray and Shellis, 2002] (instead $30 \mathrm{~s}$ as instructed), and rinsed again. Subsequently, the surface was dried. Curodont ${ }^{\mathrm{TM}}$ Repair was dissolved in $0.05 \mathrm{~mL}$ of deionized water, applied to the sample surface, and allowed to interact with the lesion for about $5 \mathrm{~min}$.

Icon ${ }^{\circledR}$ (DMG, Hamburg, Germany) was applied according to the manufacturer's instructions with the exception of the etching procedure. The surface of the lesion was etched using 37\% phosphoric acid gel (Total Etch; Vivadent) for $5 \mathrm{~s}$ [Gray and Shellis, 2002; Paris et al., 2013] (instead 120 s using $\mathrm{HCl}$ as instructed) and rinsed using distilled water for $30 \mathrm{~s}$. Then, the surface was dried using Icon Dry ${ }^{\circledR}$ for $30 \mathrm{~s}$ and infiltrated using Icon Infiltrant ${ }^{\circledR}$ for 3 min. Subsequently, excess material was removed using cotton pellets, and the resin was light-cured for $40 \mathrm{~s}$. The application of Icon Infiltrant ${ }^{\circledR}$ was repeated (1 min) and light-cured again (40 s).

Elmex fluid (10,000 ppm $\mathrm{F}^{-}$as amine fluoride, $\mathrm{pH}=3.9$; GABA Schweiz AG, Therwil, Switzerland) was applied according to the manufacturer's instructions. Elmex fluid was applied on the surface of the lesion using a soaked cotton pellet and allowed to set for about 5 min.

Tiefenfluorid $^{\circledR}\left(43,350 \mathrm{ppm} \mathrm{F}^{-}\right.$as magnesium fluorosilicate, copper-(II)-fluorosilicate, and sodium fluoride, $\mathrm{pH}=2$ ); Humanchemie $\mathrm{GmbH}$, Alfeld/Leine, Germany) was applied according to the manufacturer's instructions. The surface of the lesion was cleaned using a brush (Pro Cup No. 990/30; Hawe Neos Dental), dried, and the first solution of Tiefenfluorid ${ }^{\circledR}$ was applied using a soaked cotton pellet. Then, the second application of solution was applied, again using a soaked cotton pellet, and allowed to set for about $5 \mathrm{~min}$.

\section{pH-Cycling and Brushing}

A computer-controlled $\mathrm{pH}$-cycling and brushing machine (Department of Operative Dentistry, Periodontology and Preventive Dentistry, RWTH Aachen University, Aachen, Germany) was used to simulate oral $\mathrm{pH}$ fluctuation patterns and daily oral care (online suppl. Fig. 4; for all online suppl. material, see www.karger. com/doi/10.1159/000477215). The machine consists of 2 basins and a motor imparting a circular and a linear motion to 1 toothbrush head (Oral-B Indicator; Proctor \& Gamble, Schwalbach am Taunus, Germany). The first (small) basin stores the solution with 
the active ingredients (e.g., dentifrice slurry). The specimens are inserted in the second basin. Additionally, the second basin can be filled, flushed, and drained with 3 different solutions via controlled valves. The filling level $(250 \mathrm{~mL})$ is controlled with an optical sensor. Brushing force can be adjusted between 0 and $5 \mathrm{~N}$ by adding weights to a special device. Prior to brushing (linear motion) the brush is immerged into the slurry bath (circular motion). The machine and the vessels of the solution connected to it are stored in an incubator at $37^{\circ} \mathrm{C}$. The control valves for filling, flushing, and draining of the solutions and the motor for brushing procedure are connected to a computer-controlled program. This program can be operated either manually or automatically via an individually adjustable protocol.

\section{pH-Cycling Conditions}

The $\mathrm{pH}$-cycling lasted for 28 days and conditions were chosen with a daily schedule of 6 cycles. Specimens were consecutively subjected to a demineralizing (60 min), rinsing (30 s), remineralizing (120 min), and further rinsing (30 s) phase. During a 6-h "night" period the specimens were subjected to a remineralizing solution. The remineralization solutions contained $1.5 \mathrm{mM} \mathrm{CaCl}_{2}$, $0.9 \mathrm{mM} \mathrm{KH}_{2} \mathrm{PO}_{4}$, and $20 \mathrm{~mm}$ Hepes, $\mathrm{pH}$ 7.0. The demineralization solution contained $0.6 \mu \mathrm{M}$ methylhydroxydiphosphonate, $3 \mathrm{mM}$ $\mathrm{CaCl}_{2}, 3 \mathrm{mM} \mathrm{KH}_{2} \mathrm{PO}_{4}$, and $50 \mathrm{mM}$ acetic acid adjusted to $\mathrm{pH} 4.87$ [Buskes et al., 1985]. The $\mathrm{pH}$-cycling solutions were refreshed with every cycle. The amounts of each solution were large enough to prevent the solutions from becoming saturated with or depleted of mineral ions ( $250 \mathrm{~mL}$ solution per group and per cycle).

Twice daily, after the first and last demineralizing phase, the specimens in each group were brushed for $10 \mathrm{~s}$ (Oral-B Indicator; Proctor \& Gamble) with either fluoride-free $\left(0 \mathrm{ppm} \mathrm{F}^{-}\right.$, based on Crest Cavity Protection; Proctor \& Gamble) (group name e.g., $\mathrm{C}_{0}$ ) or $\mathrm{NaF}\left(1,100 \mathrm{ppm} \mathrm{F}^{-}\right.$; Crest Cavity Protection; Proctor \& Gamble) (e.g., $\mathrm{C}_{1}$ ) dentifrice slurry. After another $110 \mathrm{~s}$ the specimens were perfused with distilled water to remove the slurry, hence simulating the recommended brushing time of 2 min [Ganss et al., 2009]. Specimens of group $\mathrm{N}_{\mathrm{NB}}$ remained unbrushed throughout the whole $\mathrm{pH}$-cycling period (negative control).

According to the manufacturer's instructions of Curodont ${ }^{\mathrm{TM}}$ Repair, oral hygiene should be performed carefully in the first days. Therefore, specimens of $C_{1}$ and $C_{2}$ were not brushed in the first 2 days [Brunton et al., 2013].

The machine was adjusted to a constant brushing frequency of 60 strokes/min and a constant brushing load of $1.5 \mathrm{~N}$ [Wiegand et al., 2013].These settings ensured the prevention of brushing abrasion in the present study and simulated a relatively realistic brushing sequence at the lower end of the range. Dentifrice slurries were prepared with deionized water in a ratio of 1:3 (toothpaste:water) parts by weight and refreshed every 2 days [Wierichs et al., 2017].

\section{Transversal Microradiographic Analysis}

After the in vitro period thin plano-parallel sections were prepared. Changes in mineral loss $\left(\Delta \Delta \mathrm{Z}=\Delta \mathrm{Z}_{\text {baseline }}-\Delta \mathrm{Z}_{\mathrm{pH} \text {-cycle }}\right)$ and lesion depth $\left(\Delta \mathrm{LD}=\mathrm{LD}_{\text {baseline }}-\mathrm{LD}_{\mathrm{pH} \text {-cycle }}\right)$ were calculated between values after pre-demineralization and after $\mathrm{pH}$-cycling $(\Delta \Delta \mathrm{Z}$ and $\Delta \mathrm{LD})$ using transversal microradiographic images. Microradiographs of the enamel specimens were obtained and analyzed as described previously [Meyer-Lueckel et al., 2015b; Esteves-Oliveira et al., 2017]. Furthermore, graphics of mean mineral density profiles were prepared for all groups with the TMR/
WIM Calculation Program (v5.25; University of Groningen, The Netherlands) and are presented in online supplementary Figure 5 [Wierichs et al., 2017].

\section{Colorimetric Analysis}

The stability, accuracy, and reliability of colorimetric measurements were evaluated as described previously [Paris et al., 2013]. In brief, within a lightproof box and under standardized conditions (aperture of $\mathrm{f} 45$, shutter speed at $1 / 60 \mathrm{~s}$, and image ISO sensitivity 200), digital photographs were obtained using a fixed SLR camera (Nikon D7000; Nikon, Tokyo, Japan). Images were taken with a macro lens (Nikon $105 \mathrm{~mm}, 1: 2.8$; Nikon) and a ring flash (Sigma Em-140 DG, Nikon) at the following instants of times: after pre-demineralization $\left(\Delta \mathrm{E}_{\text {baseline }}\right)$, after surface treatment $\left(\Delta \mathrm{E}_{\text {treat }}\right)$, and after $\mathrm{pH}$-cycling $\left(\Delta \mathrm{E}_{\mathrm{pH} \text {-cycle }}\right)$. For colorimetric analysis the acid-resistant varnish on the sound area (window SC) was temporarily removed using acetone.

Evaluation of digital images (RAW-Format) was performed using Photoshop CS6 extended (Adobe, San Jose, CA, USA). The CIE$\mathrm{L}^{*} \mathrm{a}^{*} \mathrm{~b}^{*}$ color system were used to analyze optical results [Johnston, 2009]. It records colorimetric parameters 3 -dimensionally: lightness $\left(\mathrm{L}^{*} ; 0\right.$ to +100$)$, green-red chromacity $\left(\mathrm{a}^{*} ;-150\right.$ to +100$)$, and blueyellow chromacity $\left(b^{*} ;-100\right.$ to +150$)$. Within a window of $105 \times$ 105 picture elements the CIE-L*a*b* values were measured, and color differences $\left(\Delta \mathrm{E}_{\text {baseline }}, \Delta \mathrm{E}_{\text {treat }}, \Delta \mathrm{E}_{\mathrm{pH} \text {-cycle }}\right)$ between window SC (sound untreated enamel) and DT (treated artificial lesion) were calculated (Excel 2010; Microsoft, Redwood, CA, USA) using the equation $\Delta \mathrm{E}=\left(\left(\mathrm{L}_{\text {sound }}{ }^{*}-\mathrm{L}_{\text {caries }}{ }^{*}\right)^{2}+\left(\mathrm{b}_{\text {sound }}{ }^{*}-\mathrm{b}_{\text {caries }}{ }^{*}\right)^{2}+\left(\mathrm{a}_{\text {sound }}{ }^{*}-\right.\right.$ $\left.\left.\mathrm{a}_{\text {caries }}{ }^{*}\right)^{2}\right)^{1 / 2}$. Changes in colorimetric values $\left(\Delta \Delta \mathrm{E}_{\text {treat }}=\Delta \mathrm{E}_{\text {baseline }}-\right.$ $\Delta \mathrm{E}_{\text {treat }}$ and $\left.\Delta \Delta \mathrm{E}_{\mathrm{pH} \text {-cycle }}=\Delta \mathrm{E}_{\text {baseline }}-\Delta \mathrm{E}_{\mathrm{pH} \text {-cycle }}\right)$ were calculated.

\section{Statistical Analysis}

Data were analyzed using SPSS statistical software (SPSS 22.0; SPSS, Munich, Germany). Variables were tested for normal distribution (Shapiro-Wilk test). Within 1 experimental group changes in mineral loss and lesion depth after pre-demineralization $\left(\Delta \mathrm{Z}_{\text {baseline }} / \mathrm{LD}_{\text {baseline }}\right)$ and after $\left(\Delta \mathrm{Z}_{\mathrm{pH} \text {-cycle }} / \mathrm{LD}_{\mathrm{pH} \text {-cycle }}\right) \mathrm{pH}$-cycling were analyzed using 2 -tailed paired $t$ tests. Changes in colorimetric values after demineralization $\left(\Delta \mathrm{E}_{\text {baseline }}\right)$, after surface treatment $\left(\Delta \mathrm{E}_{\text {treat }}\right)$, and after $\mathrm{pH}$-cycling $\left(\Delta \mathrm{E}_{\mathrm{pH} \text {-cycle }}\right)$ within 1 group were analyzed using 2-tailed paired $t$ tests.

One-way ANOVA and the Bonferroni post hoc test were used for pair-wise multiple comparisons to detect differences in changes of mineral loss $(\Delta \Delta \mathrm{Z})$, lesion depth $(\Delta \mathrm{LD})$, and colorimetric values $\left(\Delta \Delta \mathrm{E}_{\text {treat }}\right.$ and $\left.\Delta \Delta \mathrm{E}_{\mathrm{pH} \text {-cycle }}\right)$. All tests were performed at a $5 \%$ level of significance.

\section{Power Calculation}

The number of specimens per group was calculated on the basis of pre-studies (nonpublished data). The a-error was set at $5 \%$. Considering the differences between the $1,100 \mathrm{ppm}$ fluoride and 0 ppm fluoride the statistical power calculated was $85 \%$ for $\Delta \Delta \mathrm{Z}$ (mean difference of 450 [SD: 600]), 89\% for $\Delta \mathrm{LD}$ (mean difference

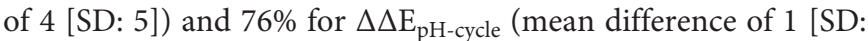
$1,5]$ ). The dropout rate was assumed not to exceed $20 \%$. Approximately 22 specimens should have been enrolled into the study for analyses of at least 18-20 specimens per groups. Since the retrospective power analysis with 18 specimens per group still provided a power of at least $92 \%$ for $\Delta \Delta \mathrm{Z}, 70 \%$ for $\Delta \mathrm{LD}$, and $81 \%$ for $\Delta \Delta \mathrm{E}_{\mathrm{pH} \text {-cycle, }}$ no additional specimens were involved in the study. 
Table 1. Mean mineral loss and lesion depth for specimens after pre-demineralization and after $\mathrm{pH}$-cycling

\begin{tabular}{|c|c|c|c|c|c|c|c|c|c|c|c|}
\hline \multirow{2}{*}{$\begin{array}{l}\begin{array}{l}\text { Inter- } \\
\text { vention }\end{array} \\
\mathrm{C}_{1}\end{array}$} & \multirow{2}{*}{$\begin{array}{l}n \\
22\end{array}$} & \multicolumn{2}{|c|}{$\Delta \mathrm{Z}_{\text {baseline }}, \mathrm{vol} \% \times \mu \mathrm{m}$} & \multicolumn{2}{|c|}{$\Delta \mathrm{Z}_{\mathrm{pH} \text {-cycling }}, \mathrm{vol} \% \times \mu \mathrm{m}$} & \multirow{2}{*}{$\begin{array}{l}p \\
<0.001\end{array}$} & \multicolumn{2}{|c|}{$\mathrm{LD}_{\text {baseline }}, \mu \mathrm{m}$} & \multicolumn{2}{|c|}{$\mathrm{LD}_{\mathrm{pH}-\mathrm{cycling}}, \mu \mathrm{m}$} & \multirow{2}{*}{$\begin{array}{l}p \\
<0.001\end{array}$} \\
\hline & & 2,971 & $(2,571 ; 3,371)^{\mathrm{A}}$ & 639 & $(4,073 ; 5,204)^{\mathrm{B}, \mathrm{C}}$ & & 136.0 & $(124.1 ; 147.9)^{\mathrm{A}}$ & 193.6 & $(178.9 ; 208.2)^{\mathrm{D}}$ & \\
\hline $\mathrm{C}_{0}$ & 21 & 2,977 & $(2,427 ; 3,528)^{\mathrm{A}}$ & 5,210 & $(4,581 ; 5,840)^{\mathrm{C}}$ & $<0.001$ & 131.4 & $(118.6 ; 144.2)^{\mathrm{A}}$ & 184.3 & $(174 ; 194.6)^{\mathrm{C}, \mathrm{D}}$ & $<0.001$ \\
\hline $\mathrm{I}_{1}$ & 22 & 2,900 & $(2,416 ; 3,383)^{\mathrm{A}}$ & 3,009 & $(2,591 ; 3,427)^{\mathrm{A}}$ & 0.239 & 138.0 & $(124.5 ; 151.6)^{\mathrm{A}}$ & 134.8 & $(126.1 ; 143.6)^{\mathrm{A}, \mathrm{B}}$ & 0.539 \\
\hline $\mathrm{I}_{0}$ & 18 & 2,747 & $(2,094 ; 3,400)^{\mathrm{A}}$ & 2,808 & $(2,302 ; 3,314)^{\mathrm{A}}$ & 0.573 & 127.2 & $(110.3 ; 144.2)^{\mathrm{A}}$ & 125.9 & $(113.3 ; 138.5)^{\mathrm{A}}$ & 0.741 \\
\hline $\mathrm{E}_{1}$ & 22 & 2,633 & $(2,194 ; 3,072)^{\mathrm{A}}$ & 2,659 & & 0.817 & 131.8 & $(119.4 ; 144.2)^{\mathrm{A}}$ & 155.8 & $(143.9 ; 167.7)^{\mathrm{A}-\mathrm{C}}$ & $<0.001$ \\
\hline $\mathrm{E}_{0}$ & 21 & 2,664 & $(2,146 ; 3,181)^{\mathrm{A}}$ & 3,395 & $(2,807 ; 3,982)^{\mathrm{A}, \mathrm{B}}$ & $<0.001$ & 123.3 & $(111.8 ; 134.8)^{\mathrm{A}}$ & 138.9 & $(125.7 ; 152.1)^{\mathrm{A}, \mathrm{B}}$ & 0.003 \\
\hline $\mathrm{T}_{1}$ & 21 & 2,289 & $(1,815 ; 2,763)^{\mathrm{A}}$ & 2,643 & $(2,054 ; 3,233)^{\mathrm{A}}$ & 0.061 & 127.2 & $(116.7 ; 137.7)^{\mathrm{A}}$ & 143.7 & $(122.5 ; 165)^{A, B}$ & 0.099 \\
\hline $\mathrm{T}_{0}$ & 19 & 2,587 & & & $(2,723 ; 3,995)^{\mathrm{A}, \mathrm{B}}$ & $<$ & 124.4 & & & $(136.7 ; 179.6)^{\mathrm{A}-\mathrm{D}}$ & 0.002 \\
\hline $\mathrm{N}_{1}$ & 21 & 2,204 & $(1,761 ; 2,647)^{\mathrm{A}}$ & 3,040 & $(2,526 ; 3,555)^{\mathrm{A}}$ & $<0.001$ & 116.8 & $(105.5 ; 128.1)^{\mathrm{A}}$ & 161.6 & $(144.2 ; 179)^{\mathrm{B}-\mathrm{D}}$ & $<0.001$ \\
\hline $\mathrm{N}_{0}$ & 21 & 2,410 & $(1,894 ; 2,927)^{\mathrm{A}}$ & 3,677 & $(3,017 ; 4,336)^{\mathrm{A}, \mathrm{B}}$ & $<0.001$ & 119.3 & $(108.3 ; 130.3)^{\mathrm{A}}$ & 159.4 & $(144.1 ; 174.7)^{\mathrm{A}-\mathrm{D}}$ & $<0.001$ \\
\hline $\mathrm{N}_{\mathrm{NB}}$ & 20 & 2,921 & $(2,395 ; 3,448)^{\mathrm{A}}$ & 4,666 & $(3,843 ; 5,489)^{\mathrm{B}, \mathrm{C}}$ & $<0.001$ & 136.7 & $(123.8 ; 149.5)^{\mathrm{A}}$ & 180.2 & $(160.8 ; 199.6)^{\mathrm{C}, \mathrm{D}}$ & $<0.001$ \\
\hline
\end{tabular}

Means (95\% confidence intervals) of mineral loss and lesions depth for specimens after pre-demineralization $\left(\Delta \mathrm{Z}_{\text {baseline }} / \mathrm{LD}\right.$ baseline $)$ and after $\mathrm{pH}$-cycling $\left(\Delta \mathrm{Z}_{\mathrm{pH} \text {-cycle }} / \mathrm{LD}_{\mathrm{pH} \text {-cycle }}\right)$. $p$ values indicate significant differences in mineral loss/lesion depth before and after $\mathrm{pH}$ cycling (2-tailed paired $t$ test). Different letters indicate significant differences between the groups for each column (large caps) $(p<0.05$; Bonferroni post hoc test). The exact $p$ values for comparison between the groups can be seen in online supplementary Table 3 .

Table 2. Mean CIE- $\mathrm{L}^{*} \mathrm{a}^{*} \mathrm{~b}^{*}$ values for specimens after pre-demineralization, after surface treatment, and after $\mathrm{pH}$-cycling

\begin{tabular}{|c|c|c|c|c|c|c|c|c|c|c|c|c|c|c|c|}
\hline \multirow{2}{*}{$\begin{array}{l}\begin{array}{l}\text { Inter- } \\
\text { ventior }\end{array} \\
\mathrm{C}_{1}\end{array}$} & \multirow{2}{*}{$\frac{n}{22}$} & \multirow{2}{*}{$\begin{array}{l}\Delta \mathrm{E}_{\text {baseline }} \\
13.1\end{array}$} & \multirow[b]{2}{*}{$(11.6 ; 14.6)$} & \multirow[b]{2}{*}{ A } & \multirow[b]{2}{*}{$\mathrm{a}, \mathrm{b}$} & \multirow{2}{*}{$\begin{array}{c}\Delta \mathrm{E}_{\text {treat }} \\
11.7\end{array}$} & \multirow[b]{2}{*}{$(10.6 ; 12.8)$} & \multirow[b]{2}{*}{ A } & \multirow[b]{2}{*}{$\mathrm{a}$} & \multirow{2}{*}{$\begin{aligned} p^{1} \\
0.127\end{aligned}$} & \multicolumn{2}{|c|}{$\Delta \mathrm{E}_{\mathrm{pH} \text {-cycle }}$} & \multirow[b]{2}{*}{$\mathrm{B}, \mathrm{C}$} & & \multirow{2}{*}{$\begin{array}{l}p^{2} \\
0.621\end{array}$} \\
\hline & & & & & & & & & & & 13.6 & $(12.6 ; 14.6)$ & & $\mathrm{b}$ & \\
\hline $\mathrm{C}_{0}$ & 22 & 13.9 & $(12.1 ; 15.7)$ & A & $\mathrm{a}$ & 12.2 & $(11.1 ; 13.4)$ & A & $\mathrm{a}$ & 0.058 & 16.4 & $(15.3 ; 17.4)$ & A & & 0.004 \\
\hline $\mathrm{I}_{1}$ & 22 & 13.9 & $(12.4 ; 15.3)$ & A & $\mathrm{a}$ & 7.9 & $(6.5 ; 9.4)$ & B & $\mathrm{b}$ & $<0.001$ & 5.6 & $(4.8 ; 6.4)$ & $\mathrm{D}$ & c & $<0.001$ \\
\hline $\mathrm{I}_{0}$ & 21 & 12.8 & $(11.4 ; 14.3)$ & A & a & 6.6 & $(5.4 ; 7.8)$ & B & $\mathrm{b}$ & $<0.001$ & 5.6 & $(4.4 ; 6.8)$ & $\mathrm{D}$ & b & $<0.001$ \\
\hline $\mathrm{E}_{1}$ & 22 & 13.5 & $(11.9 ; 15)$ & A & $\mathrm{a}$ & 12.1 & $(11 ; 13.2)$ & A & $\mathrm{a}$ & 0.055 & 10.7 & $(9.5 ; 11.9)$ & C & b & 0.004 \\
\hline $\mathrm{E}_{0}$ & 21 & 13.6 & $(11.8 ; 15.4)$ & A & a & 11.7 & $(10.5 ; 12.9)$ & A & $\mathrm{a}, \mathrm{b}$ & 0.050 & 11.7 & $(10.6 ; 12.9)$ & C & b & 0.007 \\
\hline $\mathrm{T}_{1}$ & 22 & 12.5 & $(11.213 .8)$ & A & a & 11.4 & $(10.2 ; 12.6)$ & A & a & 0.105 & 12.2 & $(10.9 ; 13.5)$ & $\mathrm{C}$ & & 0.623 \\
\hline $\mathrm{T}_{0}$ & 22 & 12.0 & $(10.2 ; 13.7)$ & A & a & 11.1 & $(9.9 ; 12.2)$ & A & a & 0.257 & 12.6 & $(11.2 ; 13.9)$ & $\mathrm{B}, \mathrm{C}$ & & 0.595 \\
\hline $\mathrm{N}_{1}$ & 22 & 12.9 & $(11.6 ; 14.2)$ & A & $\mathrm{a}$ & 12.9 & $(11.6 ; 14.2)$ & A & $\mathrm{a}$ & $\mathrm{n} / \mathrm{a}$ & 11.2 & $(9.9 ; 12.4)$ & C & D & 0.027 \\
\hline $\mathrm{N}_{0}$ & 21 & 14.0 & $(12.4 ; 15.5)$ & A & $\mathrm{a}$ & 14.0 & $(12.4 ; 15.5)$ & A & a & $\mathrm{n} / \mathrm{a}$ & 12.6 & $(10.9 ; 14.3)$ & $\mathrm{B}, \mathrm{C}$ & $\mathrm{a}$ & 0.151 \\
\hline $\mathrm{N}_{\mathrm{NB}}$ & 22 & 12.9 & $(11.1 ; 14.8)$ & A & $\mathrm{a}$ & 12.9 & $(11.1 ; 14.8)$ & A & a & $\mathrm{n} / \mathrm{a}$ & 15.2 & $(13.5 ; 17)$ & $\mathrm{A}, \mathrm{B}$ & b & $<0.001$ \\
\hline
\end{tabular}

Means (95\% confidence intervals) of the CIE-L*a*b*-values after pre-demineralization $\left(\Delta \mathrm{E}_{\text {baseline }}\right)$, after surface treatment $\left(\Delta \mathrm{E}_{\text {treat }}\right)$, and after $\mathrm{pH}$-cycling $\left(\Delta \mathrm{E}_{\mathrm{pH} \text {-cycle }}\right)$. Different letters indicate significant differences between the groups for each column (large caps) ( $p<$ 0.05 ; Bonferroni post hoc test) or within 1 group for each line (small caps) ( $p<0.05 ; 2$-tailed paired $t$ test). Furthermore, exact $p$ values are given (2-tailed paired $t$ test) for comparison between $\Delta \mathrm{E}_{\text {baseline }}$ and $\Delta \mathrm{E}_{\text {treat }}\left(p^{1}\right)$ as well as between $\Delta \mathrm{E}_{\text {baseline }}$ and $\Delta \mathrm{E}_{\mathrm{pH} \text {-cycle }}\left(p^{2}\right)$. $\mathrm{n} / \mathrm{a}$ : no intervention before $\mathrm{pH}$-cycling has been performed. The exact $p$ values for comparison between the groups can be seen in online supplementary Table 4.

\section{Results}

After pre-demineralization, subsurface lesions were created that did not differ significantly in mineral loss $(p=0.211)$, lesion depth $(p=0.164)$, and colorimetric values $(p=0.722$; ANOVA; Tables 1,2$)$ between the several treatment groups. Mean (95\% confidence intervals)
$\Delta \mathrm{Z}_{\text {baseline }}$ was $2,665 \mathrm{vol} \% \times \mu \mathrm{m}(2,522 ; 2,807), \mathrm{LD}_{\text {baseline }}$ was $128.5 \mu \mathrm{m}(124.9 ; 132.0)$, and $\Delta \mathrm{E}_{\text {baseline }}$ was 13.2 (12.7; 13.6). Due to losses during preparation, final TMR analysis was performed with $18-22$ specimens per group (Tables 1,2). All specimens revealed subsurface lesions without abrasive surface losses (online suppl. Fig. 5). 


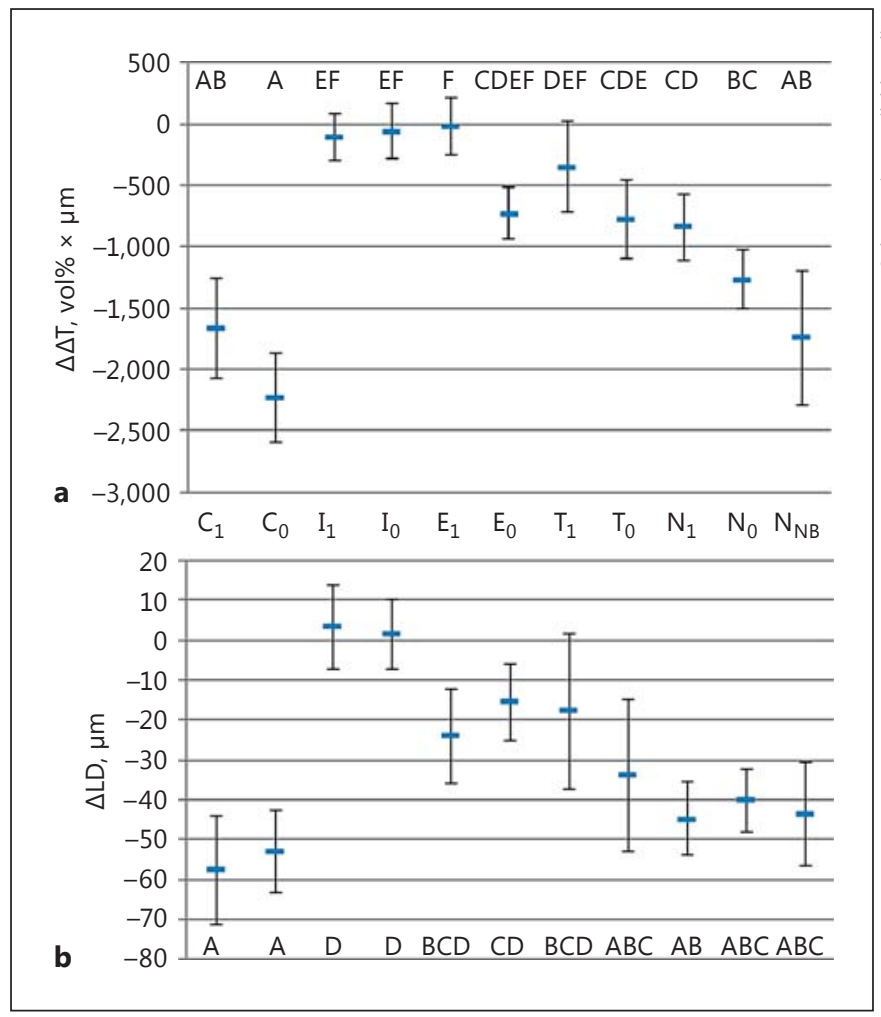

Fig. 2. Means (with $95 \%$ confidence intervals) of the changes in mineral loss $(\Delta \Delta \mathrm{Z}$; a $)$ and lesion depth $(\Delta \mathrm{LD} ; \mathbf{b})$ in the pre-demineralized area before $\left(\Delta \mathrm{Z}_{\text {baseline }} / \mathrm{LD}_{\text {baseline }}\right)$ and after $\mathrm{pH}$-cycling $\left(\Delta \mathrm{E}_{\mathrm{pH} \text {-cycle }} / \mathrm{LD}_{\mathrm{pH} \text {-cycle }}\right)$. Negative $\Delta \Delta \mathrm{Z} / \Delta \mathrm{LD}$ values indicate demineralization. Different letters indicate significant differences between the groups ( $p<0.05$; Bonferroni post hoc test). The exact $p$ values for comparison between the groups can be seen in online supplementary Table 3 .

\section{Transversal Microradiographic Analysis}

For mineral loss and lesion depth, significant changes between values after pre-demineralization and after $\mathrm{pH}$ cycling were observed for $\mathrm{C}_{0}, \mathrm{C}_{1}, \mathrm{~N}_{\mathrm{NB}}, \mathrm{N}_{0}, \mathrm{~N}_{1}, \mathrm{~T}_{0}$, and $\mathrm{E}_{0}$ $(p<0.05 ; 2$-tailed paired $t$ test; Table 1$)$, whereas for $\mathrm{E}_{1}$, $\mathrm{I}_{0}, \mathrm{I}_{1}$, and $\mathrm{T}_{1}$ no significant changes could be revealed. For comparisons between the groups, specimens of $\mathrm{C}_{0}, \mathrm{C}_{1}$, $\mathrm{N}_{\mathrm{NB}}$, and $\mathrm{N}_{0}$ showed significantly higher changes in mineral loss $(\Delta \Delta \mathrm{Z})$ than $\mathrm{E}_{1}, \mathrm{I}_{0}, \mathrm{I}_{1}$, and $\mathrm{T}_{1}(p<0.001$; Bonferroni post hoc test; Fig. 2$)$. For lesion depth $(\Delta \mathrm{LD})$, only $\mathrm{I}_{1}$ and $\mathrm{I}_{0}$ showed significantly higher values than all other groups except $\mathrm{E}_{0}, \mathrm{E}_{1}$, and $\mathrm{T}_{1}$ ( $p \leq 0.007$; Bonferroni post hoc test; Fig. 2). In general, specimens brushed with fluoride dentifrices revealed slightly less (nonsignificant) demineralization $(\Delta \Delta \mathrm{Z})$ compared with the respective specimens brushed with nonfluoride dentifrices.

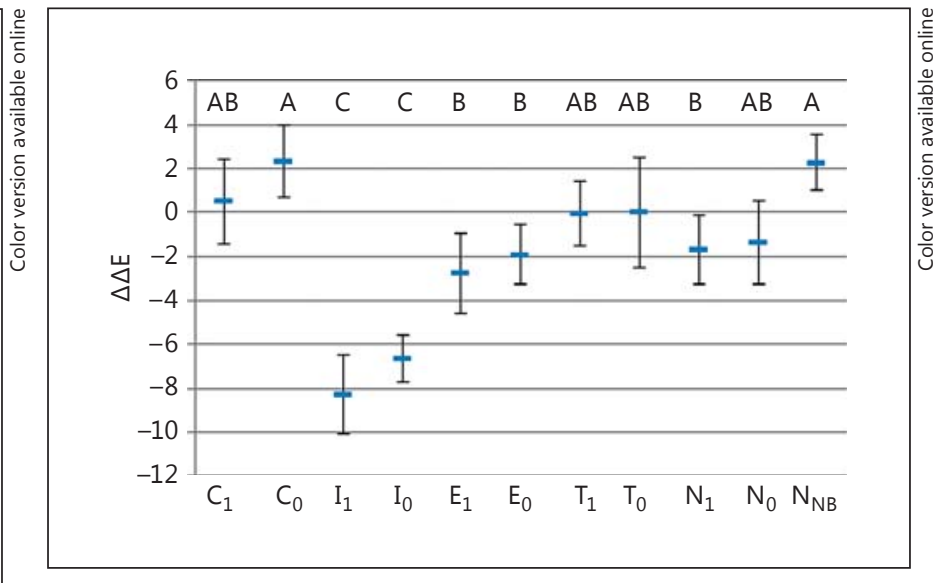

Fig. 3. Means (with $95 \%$ confidence intervals) of the changes in colorimetric values in the pre-demineralized area before $\left(\Delta \mathrm{E}_{\text {baseline }}\right)$ and after $\mathrm{pH}$-cycling $\left(\Delta \mathrm{E}_{\mathrm{pH} \text {-cycle }}\right)$. Positive $\Delta \Delta \mathrm{E}$ values indicate a masking effect. Different letters indicate significant differences between the groups for each column $(p<0.05$; Bonferroni post hoc test). The exact $p$ values for comparison between the groups can be seen in online supplementary Table 4.

\section{Colorimetric Analysis}

Intervention before $\mathrm{pH}$-cycling reduced colorimetric values $(\Delta \mathrm{E})$ in all groups, being significant only for $\mathrm{I}_{1}$ and $\mathrm{I}_{0}(p<0.001 ; 2$-tailed paired $t$ test; Table 2). Except for $\mathrm{N}_{\mathrm{NB}}, \mathrm{C}_{0}, \mathrm{C}_{1}$, and $\mathrm{T}_{0}$, all other treatments reduced the color difference between $\Delta \mathrm{E}_{\text {baseline }}$ and $\Delta \mathrm{E}_{\mathrm{pH} \text {-cycle, but only }}$ significantly for $\mathrm{I}_{1}, \mathrm{I}_{0}, \mathrm{E}_{1}, \mathrm{E}_{0}$, and $\mathrm{N}_{1}(p \leq 0.027 ; 2$-tailed paired $t$ test). Values for $\Delta \Delta \mathrm{E}$ of $\mathrm{I}_{1}, \mathrm{I}_{0}, \mathrm{E}_{1}, \mathrm{E}_{0}$, and $\mathrm{N}_{1}$ were significantly higher compared with $\mathrm{C}_{0}$ and $\mathrm{N}_{\mathrm{NB}}(p \leq$ 0.031; Bonferroni post hoc test; Fig. 3).

\section{Discussion}

The present in vitro study compared the effects of a self-assembling peptide, fluorides, and caries infiltration on artificial enamel caries lesions under (slightly) demineralizing conditions. Compared with the negative control, the application of fluorides and low-viscosity resin significantly hampered further mineral loss. Furthermore, the masking effect after the application of the lowviscosity resin was significantly better compared with all other groups. Contrastingly, the application of the selfassembling peptide could not significantly reduce further mineral loss as well as colorimetric values partially rejecting our null hypothesis that significant differences in the change of mineral loss as well as colorimetric values 
would also be observed between the peptide P11-4 and the negative controls.

For specimens treated with the self-assembling peptide P11-4 a significantly higher mineral loss was observed compared with the respective negative control samples being brushed. We speculate that one of the reasons why the additional use of P11-4 seemed to even hamper the "demineralizing inhibiting effect" of the fluoride toothpaste could be the $\mathrm{pH}$-depending reactiveness of P11-4 [Aggeli et al., 2003]. At $\mathrm{pH}>7.2$, P11-4 is obtained as an isotropic fluid which is supposed to transform into a viscous birefringent nematic state in the $\mathrm{pH}$ range 5.0-7.0 [Aggeli et al., 2003]. In the nematic state P11-4 seems to promote remineralization in vitro [Kirkham et al., 2007; Jablonski-Momeni and HeinzelGutenbrunner, 2014; Schmidlin et al., 2016] by presumably diffusing into the lesions and producing 3-dimensional gels comprising $\beta$-sheet aggregates [Aggeli et al., 2003]. Therefore, it might be speculated that an effect of the enhanced incorporation of $\mathrm{Ca}^{2+}$ and $\mathrm{PO}_{4}{ }^{3-}$ from saliva (and thus pronounced remineralization) after the application of the self-assembling peptide might be observed in the same setting but under net-remineralizing conditions. However, intermittent demineralizing conditions are common in the oral environment, in particular for proximal areas, where both caries infiltration and Curodont $^{\mathrm{TM}}$ Repair are indicated. When $\mathrm{pH}$ decreases $(3.2<\mathrm{pH}<5.0)$ flocculation of the peptide can be observed [Aggeli et al., 2003]. This also seems to occur when $\mathrm{pH}$ changes several times; the concomitant increase in ionic strength seemed to lead to flocculation after approximately 4 "pH jumps" [Aggeli et al., 2003]. Thus, in the present study in which $\mathrm{pH}$ fluctuation was simulated by using daily $(n=6)$ periodic changes between remineralization ( $\mathrm{pH} \mathrm{7.0)}$ and demineralization $(\mathrm{pH} 4.87)$ solutions, the nematic state of the peptide presumably changed into a "flocculated state." The flocculated peptide is relatively unreactive [Aggeli et al., 2003]. Thus, remineralization is no longer promoted. Contrastingly, when the peptide flocculates after being incorporated into the enamel, the unreactive precipitate seems to even hamper the diffusion of ions (including $\mathrm{F}^{-}, \mathrm{Ca}^{2+}$, and $\mathrm{PO}_{4}{ }^{3-}$ ) to the enamel surface during remineralization periods, resulting in a smaller fluoride availability that effectively protects the crystal from dissolution during the subsequent demineralization periods.

In the present study only caries infiltration was capable of masking the initial caries lesion after treatment as well as after subsequent $\mathrm{pH}$-cycling. This is in agreement with previous in vitro [Rocha Gomes Torres et al., 2011; Paris

Self-Assembling Peptide P11-4 et al., 2013] and in vivo studies [Kim et al., 2011; Knosel et al., 2013]. Due to the similar RI of the infiltrant (1.52) [Paris et al., 2013] compared with apatite, light scattering is reduced and visual color differences to enamel are decreased directly after application. P11-4 is presumed to mask initial lesions by reversing the caries lesions under (ideal) remineralizing conditions [Jablonski-Momeni and Heinzel-Gutenbrunner, 2014]. However, data from controlled clinical studies are inconclusive [Brunton et al., 2013]. Interestingly, the application of P11-4 could not induce a significant change in colorimetric values under the present conditions due to the missing remineralization, as discussed above.

In the present study the surfaces of the lesions treated with Curodont ${ }^{\mathrm{TM}}$ Repair or Icon ${ }^{\circledR}$ were both etched with phosphoric acid for $5 \mathrm{~s}$. This is in contrast to the manufacturers' instructions. For Icon ${ }^{\circledR}$ the application of hydrochloric acid for $2 \mathrm{~min}$ is recommended and for Curodont $^{\mathrm{TM}}$ Repair the application of phosphoric acid for $30 \mathrm{~s}$. However, it could be shown previously that for artificial caries lesions the relatively short etching time is sufficient to open up the pores of subsurface lesions for caries infiltration [Gray and Shellis, 2002; Paris et al., 2013]. It has been shown that the surface integrity of white spots was disrupted when phosphoric acid was applied for $10 \mathrm{~s}$ or longer [Gray and Shellis, 2002]. Thus, to ensure an intact, noncavitated surface, specimens treated with the self-assembling peptide or the low-viscosity resin were not etched as proposed by the manufacturer.

In the present study pre-demineralized ( 21 days of demineralization) caries-like enamel lesions with a mean lesion depth of approximately $130 \mu \mathrm{m}$ were used to analyze re- and demineralization characteristics. Although the lesion depths of the specimens in the present study can be considered as deep when compared with lesion depths used in recent in vitro and in situ studies [Meyer-Lueckel et al., 2015a; Souza et al., 2015; Wierichs et al., 2016, 2017], the lesions can be considered "subclinical" from a clinical point of view. Some of them would probably even be difficult to detect in vivo [ten Cate et al., 2008]. However, the central aim of the present study was to compare different treatment methods regarding their ability to hamper slight demineralization. The anticaries effect of fluoride is assumed to be limited to the outer $150-200 \mu \mathrm{m}$ of the lesion (at deeper levels no difference was observed compared with placebo) [ten Cate and Rempt, 1986; White and Featherstone, 1987; Bjarnason and Finnbogason, 1991], thus, we decided to use rather shallow lesions to analyze different methods regarding their ability to influence the demineralizing of "subclinical" caries lesions.

Caries Res 2017;51:451-459

DOI: $10.1159 / 000477215$ 
However, various types of deeper lesions formed both in vitro and in vivo [Al-Khateeb et al., 2002] should be analyzed in further studies - firstly, to get more information about the tested agent; secondly, to get more information about the model being used; and thirdly, to choose the perfect setting for the scientific hypothesis under investigation (before performing clinical studies).

The concentration of fluorides in oral fluids is maintained by the release of ions from bioavailable reservoirs on the teeth, oral mucosa, and dental plaque [Vogel, 2011]. Since most of the fluoride reservoirs are mediated by calcium [Vogel, 2011], several methods to modulate the calcium concentration have been developed. In the present study the calcium concentration for Tiefenfluorid $^{\circledR}$ should have been increased by the consecutive application of 2 solutions. The first solution contained a high concentration of magnesium fluorosilicate, copper(II)-fluorosilicate, and sodium fluoride, and the second contained calcium hydroxide. By the precipitation reaction of a magnesium fluorosilicate solution with calcium hydroxide, $\mathrm{CaF}_{2}$-like precipitations are supposed to be deposited on the enamel and in the enamel porosities [Buchalla et al., 2007]. Thus, the bioavailability of $\mathrm{Ca}^{2+}$ and $\mathrm{PO}_{4}{ }^{3-}$ ions was supposed to be increased, which should have resulted in a more pronounced mineral gain. Interestingly, this effect could neither be observed in a previous study [Buchalla et al., 2007] nor in the present study. In the previous study no difference in the $\mathrm{KOH}$ soluble fluoride content on the surface as well as in the structurally bound fluoride content in the outer $100 \mu \mathrm{m}$ could be observed compared with a fluoride solution, but for both compared with the negative control (no fluoride application). In the present study no difference in the demineralizing inhibitory effect could be found when compared with an amine fluoride solution.

For colorimetric analysis the used CIE-L*a*b* color system enables the evaluation of not only different areas, but also of changes in colorimetric values of one area over time, if one "reference area" remains unchanged. In the present study the sound untreated enamel (window SC) served as the "intra-specimen" reference area to analyze the change in $\Delta \mathrm{E}$ of the treated artificial lesion (window DT) after the treatments as well as after subsequent $\mathrm{pH}$ cycling. Therefore, sound untreated enamel had to be protected during treatment and $\mathrm{pH}$-cycling. Care was taken to apply and remove the "protective" nail varnish. However, the CIE-L*a*b* values of sound untreated enamel slightly changed over time. Although no significant differences in the slight increase of the CIE-L*a*b* values could be observed between the groups, it might be speculated that if the reference area had remained unchanged, the colorimetric differences between sound untreated enamel and the treated artificial lesion after surface treatment $\left(\Delta \mathrm{E}_{\text {treat }}\right)$ and after $\mathrm{pH}$-cycling $\left(\Delta \mathrm{E}_{\mathrm{pH} \text {-cycle }}\right)$ would have been greater. Consequently, $\Delta \Delta \mathrm{E}_{\text {treat }}$ and $\Delta \Delta \mathrm{E}_{\mathrm{pH} \text {-cycle }}$ as well as differences between the groups would be slightly smaller. However, the results of the colorimetric analysis are in accordance with the results of the transversal microradiography. Furthermore, absolute colorimetric results and the measured color differences between materials should be interpreted with caution [Paris et al., 2013], irrespectively of slight alterations of the reference area. Thus, digital imaging as performed in the present study seems to be suitable for evaluating color differences between specimens.

It can be concluded that under the in vitro conditions chosen the used highly concentrated fluorides inhibited further lesion progression but could not mask the unfavorable appearance of the white spot lesions considerably. Caries infiltration could simultaneously arrest and mask the lesion, whereas a self-assembling peptide could neither inhibit further lesion progression nor mask the lesions.

\section{Acknowledgments}

This study was funded by the authors and their institution. This study was conducted as part of the doctoral thesis of J.K. We would like to thank Rainer Dautzenberg, Axel Honné, and the whole team of the scientific construction laboratory of the RWTH Aachen University for developing, constructing, and assembling the computer-controlled $\mathrm{pH}$-cycling and brushing machine. Furthermore, we would like to thank the staff of Klaus Mussler Ingenieurbüro for their excellent collaboration and technical assistance.

\section{Disclosure Statement}

The authors declare no potential conflicts of interests with respect to the authorship and/or publication of this article. H.M.-L. receives a research grant and royalties from DMG, the manufacturer of $\mathrm{ICON}^{\circledR}$.

\section{Author Contributions}

R.J.W., H.M.-L., J.K., and J.L. designed and planned the study; J.K. prepared the samples; R.J.W. and J.K. performed the measurements and statistical analysis; R.J.W. wrote the manuscript; M.E.-O and H.M.-L. commented on the paper, and all authors revised the manuscript. 


\section{References}

Aggeli A, Bell M, Boden N, Keen JN, Knowles PF, McLeish TC, Pitkeathly M, Radford SE: Responsive gels formed by the spontaneous selfassembly of peptides into polymeric $\beta$-sheet tapes. Nature 1997;386:259-262.

Aggeli A, Bell M, Carrick LM, Fishwick CW, Harding R, Mawer PJ, Radford SE, Strong AE, Boden $\mathrm{N}$ : $\mathrm{pH}$ as a trigger of peptide $\beta$-sheet self-assembly and reversible switching between nematic and isotropic phases. J Am Chem Soc 2003;125:9619-9628.

Akin M, Basciftci FA: Can white spot lesions be treated effectively? Angle Orthod 2012;82: 770-775.

Al-Khateeb S, Exterkate RA, de Josselin de Jong E, Angmar-Mansson B, ten Cate JM: Light-induced fluorescence studies on dehydration of incipient enamel lesions. Caries Res 2002;36: 25-30.

Altenburger MJ, Gmeiner B, Hellwig E, Wrbas KT, Schirrmeister JF: The evaluation of fluorescence changes after application of casein phosphopeptides (CPP) and amorphous calcium phosphate (ACP) on early carious lesions. Am J Dent 2010;23:188-192.

Bailey DL, Adams GG, Tsao CE, Hyslop A, Escobar K, Manton DJ, Reynolds EC, Morgan MV: Regression of post-orthodontic lesions by a remineralizing cream. J Dent Res 2009;88: 1148-1153.

Bjarnason S, Finnbogason SY: Effect of different fluoride levels in dentifrice on the development of approximal caries. Caries Res 1991; 25:207-212.

Boersma JG, van der Veen MH, Lagerweij MD, Bokhout B, Prahl-Andersen B: Caries prevalence measured with QLF after treatment with fixed orthodontic appliances: influencing factors. Caries Res 2005;39:41-47.

Brunton PA, Davies RP, Burke JL, Smith A, Aggeli A, Brookes SJ, Kirkham J: Treatment of early caries lesions using biomimetic self-assembling peptides - a clinical safety trial. $\mathrm{Br}$ Dent J 2013;215:E6.

Buchalla W, Lennon AM, Trage K, Becker K, Attin T: Enamel fluoride uptake following fluoride application and fluoride precipitation (in German). Schweiz Monatsschr Zahnmed 2007;117:118-122.

Buskes JA, Christoffersen J, Arends J: Lesion formation and lesion remineralization in enamel under constant composition conditions. A new technique with applications. Caries Res 1985;19:490-496.

Esteves-Oliveira M, Santos NM, Meyer-Lueckel $\mathrm{H}$, Wierichs RJ, Rodrigues JA: Caries-preventive effect of anti-erosive and nano-hydroxyapatite-containing toothpastes in vitro. Clin Oral Investig 2017;21:291-300.

Ganss C, Schlueter N, Preiss S, Klimek J: Tooth brushing habits in uninstructed adults - frequency, technique, duration and force. Clin Oral Investig 2009;13:203-208.
Gorelick L, Geiger AM, Gwinnett AJ: Incidence of white spot formation after bonding and banding. Am J Orthod 1982;81:93-98.

Gray GB, Shellis P: Infiltration of resin into white spot caries-like lesions of enamel: an in vitro study. Eur J Prosthodont Restor Dent 2002; 10:27-32.

Holmen L, Thylstrup A, Ogaard B, Kragh F: A scanning electron microscopic study of progressive stages of enamel caries in vivo. Caries Res 1985;19:355-367.

Jablonski-Momeni A, Heinzel-Gutenbrunner M: Efficacy of the self-assembling peptide p11-4 in constructing a remineralization scaffold on artificially-induced enamel lesions on smooth surfaces. J Orofac Orthop 2014;75:175-190.

Johnston WM: Color measurement in dentistry. J Dent 2009;37(suppl 1):e2-e6.

Kidd EA, Fejerskov O: What constitutes dental caries? Histopathology of carious enamel and dentin related to the action of cariogenic biofilms. J Dent Res 2004;83:C35-C38.

Kim S, Kim EY, Jeong TS, Kim JW: The evaluation of resin infiltration for masking labial enamel white spot lesions. Int J Paediatr Dent 2011;21:241-248.

Kirkham J, Firth A, Vernals D, Boden N, Robinson C, Shore RC, Brookes SJ, Aggeli A: Selfassembling peptide scaffolds promote enamel remineralization. J Dent Res 2007;86:426430.

Knosel M, Eckstein A, Helms HJ: Durability of esthetic improvement following icon resin infiltration of multibracket-induced white spot lesions compared with no therapy over 6 months: a single-center, split-mouth, randomized clinical trial. Am J Orthod Dentofacial Orthop 2013;144:86-96.

Meireles SS, Andre Dde A, Leida FL, Bocangel JS, Demarco FF: Surface roughness and enamel loss with two microabrasion techniques. J Contemp Dent Pract 2009;10:58-65.

Meyer-Lueckel H, Paris S: Caries infiltration; in Meyer-Lueckel H, Paris S, Ekstrand KR (eds): Caries Management - Science and Clinical Practice. Stuttgart, Thieme, 2013, pp 246255.

Meyer-Lueckel H, Wierichs RJ, Gninka B, Heldmann P, Dorfer CE, Paris S: The effect of various model parameters on enamel caries lesions in a dose-response model in situ. J Dent 2015a;43:1261-1267.

Meyer-Lueckel H, Wierichs RJ, Schellwien T, Paris S: Remineralizing efficacy of a CPP-ACP cream on enamel caries lesions in situ. Caries Res 2015b;49:56-62.

Michaelis W, Schiffner U: The Fourth German Oral Health Study (DMS IV). Cologne, Institute of German Dentists (IDZ), 2006.
Paris S, Meyer-Lueckel H, Kielbassa AM: Resin infiltration of natural caries lesions. J Dent Res 2007;86:662-666.

Paris S, Schwendicke F, Keltsch J, Dorfer C, Meyer-Lueckel H: Masking of white spot lesions by resin infiltration in vitro. J Dent 2013; 41(suppl 5):e28-e34.

Rocha Gomes Torres C, Borges AB, Torres LM, Gomes IS, de Oliveira RS: Effect of caries infiltration technique and fluoride therapy on the colour masking of white spot lesions. J Dent 2011;39:202-207.

Schmidlin P, Zobrist K, Attin T, Wegehaupt F: In vitro re-hardening of artificial enamel caries lesions using enamel matrix proteins or selfassembling peptides. J Appl Oral Sci 2016;24: 31-36.

Souza BM, Comar LP, Vertuan M, Fernandes Neto C, Buzalaf MA, Magalhaes AC: Effect of an experimental paste with hydroxyapatite nanoparticles and fluoride on dental demineralisation and remineralisation in situ. Caries Res 2015;49:499-507.

ten Cate JM, Buijs MJ, Miller CC, Exterkate RA: Elevated fluoride products enhance remineralization of advanced enamel lesions. J Dent Res 2008;87:943-947.

ten Cate JM, Rempt HE: Comparison of the in vivo effect of a 0 and 1,500 ppmF MFP toothpaste on fluoride uptake, acid resistance and lesion remineralization. Caries Res 1986;20: 193-201.

Vogel GL: Oral fluoride reservoirs and the prevention of dental caries. Monogr Oral Sci 2011;22:146-157.

Waggoner WF, Johnston WM, Schumann S, Schikowski E: Microabrasion of human enamel in vitro using hydrochloric acid and pumice. Pediatr Dent 1989;11:319-323.

White DJ, Featherstone JD: A longitudinal microhardness analysis of fluoride dentifrice effects on lesion progression in vitro. Caries Res 1987;21:502-512.

Wiegand A, Burkhard JP, Eggmann F, Attin T: Brushing force of manual and sonic toothbrushes affects dental hard tissue abrasion. Clin Oral Investig 2013;17:815-822.

Wierichs RJ, Lausch J, Meyer-Lueckel H, EstevesOliveira M: Re- and demineralization characteristics of enamel depending on baseline mineral loss and lesion depth in situ. Caries Res 2016;50:141-150.

Wierichs RJ, Zelck H, Doerfer CE, Appel P, Paris S, Esteves-Oliveira M, Meyer-Lueckel H: Effects of dentifrices differing in fluoride compounds on artificial enamel caries lesions in vitro. Odontology 2017;105:36-45.

Willmot DR: White lesions after orthodontic treatment: does low fluoride make a difference? J Orthod 2004;31:235-242. 